\title{
Discourse on Adolescent Deviant Behavior on Social Media Facebook: Indonesian Youth Group Caption
}

\author{
Novita Ely ${ }^{1, a^{*}}$, Warsono $^{1, b}$ \& and Wisnu ${ }^{1, c}$ \\ ${ }^{1}$ Department of Social Studies Education, Postgraduate, State University of Surabaya, Surabaya, 60213, Indonesia \\ ely.18001@mhs.unesa.ac.id \\ *Corresponding Author: ely.18001@mhs.unesa.ac.id
}

\begin{abstract}
This study aims to determine the content or discourse of deviant behavior by teenagers on Facebook social media and to find out which vocabulary is most widely used by Indonesian teenage grub caption members. This type of research is qualitative with content analysis methods. The subjects of this study were members of the Indonesian Youth Caption group, while the informants used the internet. Based on the results of the analysis and discussion of the data, it shows that the discourse on deviant behavior by teenagers in the Facebook Social Media Grub is: (1) Sharing pornographic videos in the form of adult films or real videos of teenagers who commit deviations, out of habit, and follow what other grub members do, (2) Share pornographic links that can be accessed by members via YouTube or WhatsApp and vent things they cannot do in their daily life, (3) Share pornographic photos for entertainment, are influenced by uploads fellow members, get audience and attention. Then the vocabulary that is often used by teenagers on the Facebook Social Media Grub, namely: (1) Sange, a sentence for men who already understand the adult world, is often used in everyday life, especially teenage boys, slang, and words. which leads to negative and dirty things, (2) Whatsapp media is used to get videos that are is viral, (3) Chat for women because they are used to seeing uploads made by young women, are interested, and feel bored with male friendships.
\end{abstract}

Keywords: Discourse; Deviant Behavior; Facebook; ndonesion Youth Group Caption;

\section{Introduction}

The Education is a continuous and never-ending process, so that it can produce a sustainable quality, aimed at the embodiment of the human figure of the future, and rooted in the cultural values of the nation and Pancasila. So that education begins to be viewed in a philosophical manner which refers to clarity based on education itself (Mulyasa, 2012). In the world of education, we cannot be separated from what is called a teenager, because adolescents themselves are a product of education in which there is Social Science which teaches students basic knowledge and skills that are useful for their daily lives. Adolescence is a transitional period in the human life span that connects childhood to adulthood (Gunarsa, 2004). Law Number 20 of 2003 concerning the National Education System states that the goal of national education is to develop the potential of students to become human beings who believe and fear God Almighty, have a noble character, are healthy, knowledgeable, capable, creative, independent, and become citizens democratic and responsible.

However, in reality, there are still many students who do not understand the purpose of education, they only carry out their obligations as students to study diligently. For students the internet also has positive and negative impacts, if they use the internet for learning, it can be categorized that the internet has a good impact. And if the internet is used to play social media and other things that are not important, it can be said that the internet has a negative impact. Advances in technology are increasingly contributing to young people's adoption of social media, a term often used interchangeably with Web 2.0, to refer to online applications that promote users, their interconnections, and user-generated content (Barnes, 2006; Cormode \& Krishnamurthy, 2008). Ninety percent of school-aged adolescents now use the Internet regularly, with over 75\% of adolescents aged 12 to 17 using social media (DeBell \& Chapman, 2006; Lenhart, Arafeh, Smith, \& Macgill, 2008). Conceptually, social media appears to contain a social constructivist view of knowledge as decentralized, accessible and built together by and among a broad user base (Greenhow et al., 2009).The widespread use of social media then forms a new social interaction in the form of a Social Network, which is a social structure formed by individuals or groups that are connected by one or more interdependent factors, 
such as friendship, brotherhood, common interests, trade, dislike, dating, common beliefs, knowledge, and prestige (Pescosolido, 2011). One of the media that is often accessed by teenagers is Facebook because it is very easy to use and is almost popular with teenagers all over the world. Apart from communicating privately and privately, Facebook can also be used to communicate in general. Based on the results of the Social survey (2018), the social media platform most often used by people globally is Facebook with 2,167 million active users. Whereas globally, in January 2018 out of 4 billion people who use the internet, there are 3.2 billion active users of social media (Kemp, 2018). Grub on social media Facebook is made by someone for something that might harm or damage the morale of the students who are members of the group. One of them is a teacher called the "Indonesian Youth Caption Group" where their members are some students from junior high schools in various cities. According to Dowdell et al., (2011) the easiest way today for offenders to meet and engage a child or teenager for sexual harassment, pornography, or prostitution is via the internet. It can be said, if "Youth Grub Caption" has more negative than positive impacts, it can all be seen from what they share in the group. Starting from photos, videos, and sharing links about pornography. It all becomes a natural thing when entering the grub, there are no good posts, all are related to negative things. It should be realized that the various features possessed by social media accustom people to live and present a "likable" life (Jurgenson, 2012).

Based on the previous description, we can argue whether the goals of education in Indonesia have been successful or not. Because in reality, students cannot develop their potential to have religious-spiritual strength, self-control, personality, intelligence, noble morals, and the skills needed by themselves, society, nation, and state so that they can avoid forms of juvenile delinquency that provide negative impact. Changes in the curriculum from year to year are policies taken by the government. The reason for the government making changes to the new education curriculum is because the previous curriculum failed to instill good values and form a strong character for students and also to improve the quality of education in Indonesia. However, the goals of the government must be in line with the realities on the ground so that the government does not go to waste when making curriculum changes. The curriculum is positioned as a selection of aspects that are considered important in preparing students to face life's challenges and represent the subject and rational dimensions of curriculum developers (Li, 2009; Goodson \& Cricks, 2009).

\subsection{Discourse on Adolescent Deviant Beahvior on Social Media}

A set of propositions that are interconnected to produce a sense of cohesion or a sense of cohesion for the listener or reader. Cohesion or cohesiveness itself must arise from the content of the discourse, but a lot of the sense of cohesiveness felt by the listener or reader must arise from the way of conveying, namely the utterance of the discourse (Sumarlam, 2003). Meanwhile, according to Chaer (2007) discourse is the most complete language unit, so that in the grammatical hierarchy it is the highest or largest grammatical unit. Meanwhile, Johnstone (2017) in his book Discourse Analysis states that discourse is real communication with language as the medium. Communication events in the form of discourse can be differentiated based on the channels used or based on important things. Based on the means channeled there is the discourse that uses spoken language (spoken discourse) and discourse that uses written language (written discussion). Based on the importance there is a transactional discourse if what is concerned with the content of the communication is an interactional discourse, if what is concerned with reciprocity (Budiman, 2004). Experts have made explanations about discourse in a variety of ways, as well as when clarifying a discourse. Based on its form or type, discourse is divided into descriptive, narrative, expository, persuasive, and argumentative discourse (Darma, 2014). Meanwhile, Mulyana (2005) states written discourse is a type of discourse that is conveyed through writing. Various forms of discourse can be presented or realized through writing. However, currently writing discourse is often used by teenagers for negative things, as is now done by grub members on social media. They often share photos, videos, and links about pornographic acts.

Deviant behavior is an action that is not following or cannot conform to the norms prevailing in the society. The act of deviant behavior is carried out either consciously or unconsciously (Rochaniningsih, 2014). Deviant behavior is the behavior of community members who are deemed not following the prevailing social customs, rules, or norms. In simple terms, it can be said that a person can behave defiantly if according to the opinion of the majority of society (at least in a certain group or community) the behavior or action is outside of the prevailing habits, customs, rules, values, or social norms (Narwoko \& Suyanto, 2010). Every human behavior and action is not only based on outward instincts but humans carry out all their behavior and actions based on norms and social controls in society. According to moral values, human behavior can also be divided into behavior that can be done (generally acceptable) and behavior that cannot be accepted by others (Jacky, 2015). According to Gillin, deviant behavior is behavior that deviates from the social norms and values of the family and society which is the cause of waning group ties and solidarity. Deviant behavior is known as the term "delinquency" which comes from the Latin word "deliuere" which means being neglected, ignoring, which is then expanded to become evil, anti-social, criminal, violating 
rules, rioters, troublemakers, terrorists, and beyond repair (Kartono, 2014). Bruce J. Cohen (2003) argues that deviant behavior is any behavior that does not succeed in adapting to the will of the community or certain groups in society. In line with the Encyclopedia Britannica pornography, the depiction of erotic behavior in books, pictures, statues, films, and so on, can cause sexual stimulation (Engel, 2012). Thus, anyone who presents pictures, writings, or shows that indulge in their genitals, causing sexual lust or desires, provoking lust and eroticism, is considered to be involved in pornographic acts. According to Horton \& Hunt (1996), the characteristics that can be identified from deviant behavior are as follows:

1) An act is called deviant if the act is declared deviant.

2) The deviation occurs as a consequence of the existence of regulations and the application of sanctions that have been carried out by others against the deviant offender.

3) There are deviant behaviors that are acceptable and some are rejected.

4) The majority of people do not fully comply with the rules so that there are disguised and absolute forms of deviance.

Adolescents, in the original language adolescence, comes from the Latin adollescere which means "to grow or grow to achieve victory". Further development, the term adolescence, actually has a broad meaning, including mental, emotional, and physical maturity (Hurlock, 1991 in Ali, 2008, p 9). According to Kartono (1995, p.148) "adolescence is also known as a link between childhood and adulthood". In this period there were major and essential changes regarding the death of spiritual and physical functions, especially sexual functions.

Juvenile delinquency can be started from trial and error which can then lead to deviant behavior. How big the deviation occurs determines the level of juvenile delinquency committed and how much impact it has. According to Gunarsa (2004), the adaptation process is more of a lifelong process (life long process) and humans are constantly trying to find and overcome the pressures and challenges of life to achieve a healthy personality. Good or bad adjustment response can simply be viewed as an individual effort. to reduce or away from tension and to maintain conditions of a more reasonable equilibrium. The transitional period of development and growth faced by adolescents is due to various physical, social, and emotional changes, all of which will cause anxiety and discomfort. As a result, this period is also known as a period full of storms and stresses, because adolescents must learn to adapt and accept all the changes that often cause emotional upheaval in them. According to Ginanjar, if the activities that adolescents undertake together with their peers are not sufficient to meet the demands of their energy turmoil, adolescents often exert their excess energy in a negative direction, such as committing social deviations by teenagers on social media. These are all forms of giving from youths that they cannot do in real life (Hidayati \& Farid 2016). The emergence of social media as a new space for interaction, making it easier for teenagers and increasing their curiosity about the wider world. Social media is also used as a means of satisfying both positive and negative desires that they cannot do in the real world. Adolescents who are still in the transition to adulthood, often try and explore new activities in the context of finding their identity in society. The internet and the development of information technology are potential tools for deviant and destructive behavior in the lives of adolescents that make them victims online (Ybarra et al., 2007; Dowdell et al., 2011; Staksrud et al, 2013).

Sharing photos, videos, or links about pornography is an example of the negative impact of social media and has become a natural thing in the context of using social media, especially in the grub caption of Indonesian teenagers. Not infrequently, what they do on social media is carried over to the real world. Verbal harassment that is mostly experienced by women is still the same, only in a different form. Words that were once spoken directly are now transformed into unpleasant writing, seduction, and even videos.

The social deviation can occur anywhere and can be done by anyone, especially teenagers today. As according to Horton \& Hunt (1987) that almost all normal people must have committed deviant actions from time to time, only the levels may differ and within certain limits. The extent to which these deviations occur, large or small, on a broad or narrow scale will certainly result in disruption of the balance of life in society. The deviant behavior described in this study is deviant behavior which is implemented in the form of content or discourse in grub on social media Facebook. Why can it be said to be deviant, because what they write or share on social media violates ethics when social media and ethics in community groups. The discourse they share is usually in the form of content that leads to pornography. Pornography itself comes from the word porn? (prostitution or prostitution) and graphein (writing). In the Encarta Reference Library (Downs, 2005), it is said that pornography is anything that is materially in the form of films, newspapers, writings, photos, or others, causing the emergence or emergence of sexual desires.

The objectives of this study are described as follows:

1. To find out the content or discourse on deviant behavior by teenagers on Facebook social media

2. To find out which words are most widely used by Indonesian youth grub caption members 


\section{Methods}

This type of research is qualitative using content analysis. A model used to examine data documentation in the form of text, images, symbols, and so on with systematic techniques for analyzing message content and processing messages, or a tool for observing and analyzing the open communication behavior of selected communicators (Moleong, 2017). The subjects of this study were members of the Indonesian Youth Caption group. Meanwhile, the research informants used the internet network. Researchers are also members of the grub so they can see the content in the Indonesian Youth Caption grub. Such as The spread of photos, videos, or links about pornography and words that are often used in the grub.

The focus of this research is content or discourse on deviant behavior on social media Facebook. The deviant behavior in the Facebook group is in the form of spreading photos, videos, or links about pornography. The dissemination process does not only occur because of the technology that allows it to be disseminated but because of the culture that exists in social media to redistribute the photos, videos, and links they have obtained. Also, teenagers often write words in grub. The most common words are usually solicitation and appeal rather than attracting the opposite sex to respond.

The technique of collecting data is by reading, capturing and summarizing the content on the Facebook group, especially content that indicates deviant behavior such as The spread of photos, videos, links, and words that are often used by teenagers on the Facebook social media group. The research data were taken within 1 month.

\section{Results And Discussions}

\section{Analysis of the Process of Youth Joining the Grub in Studying Criminal Actions}

The process of studying juvenile delinquency behavior can be seen in dimensions according to Sutherland's proposition. The result has been that the nine principles of differential association theory have become four names as differential reinforcement of criminal behavior (Burgess \& Akers, 1966).

\section{Learned criminal behavior is not inherited}

In these groups, the learning process is carried out in groups seeing or observing the grub groups on Facebook social media. There are several examples of behavior that could become a crime if members forget about the norms and laws that exist in society. Distributing pornographic photos, videos, or links includes the behavior of teenagers in the grub and can be called a crime because it has a detrimental impact on other people and members who follow them. With the support of the group to protect fellow grub members, they will do things that can benefit or even harm other grub members. In the members of the Indonesian Youth Grub Caption, the researchers found and captured posts that contained pornographic video elements as shown in Figure 1 below.

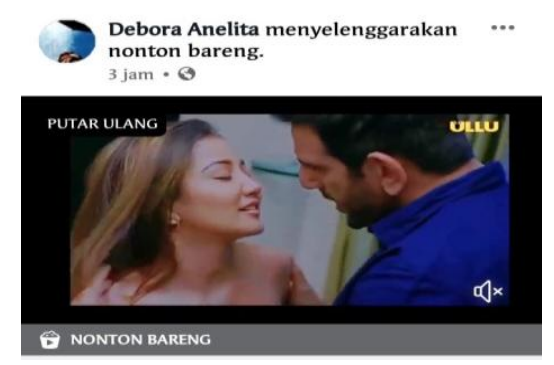

Figure 1. Capture Pornographic Videos

This can be done and sometimes triggers conflicts in grub because they will cheer up in the comments column if there is an account that triggers a conflict.

\section{Criminal behavior is learned in interactions through friends and communication}

The criminal behavior learned by grub members is due to the learning process obtained from the group so that it slowly replaces the role of the family and at this point, an individual looks for a place to find comfort. And in this position, the Indonesian Youth Grub Caption becomes an intimate group for its members so that they feel comfortable in the conditions in the group circle. Interactions that occur with friends through social media communication and can also be intimate through exchanging WhatsApp contacts. After the communication takes place, the next point is to keep communication running as it should be according to the values that previously made them comfortable in the group. Female members of the Indonesian Youth Grub Caption feel that the behavior of uploading photos, videos, or words is also influenced by the friendly 
environment that joins the grub and then invites other friends to join the grub. This shows that a process of cultivating children's personality traits depends on a lesson they receive in the family environment so that it is not affected by the child's play environment.

The following are the words that are often used by members of the Indonesian Youth Grub Caption, which are presented in Figure 2.

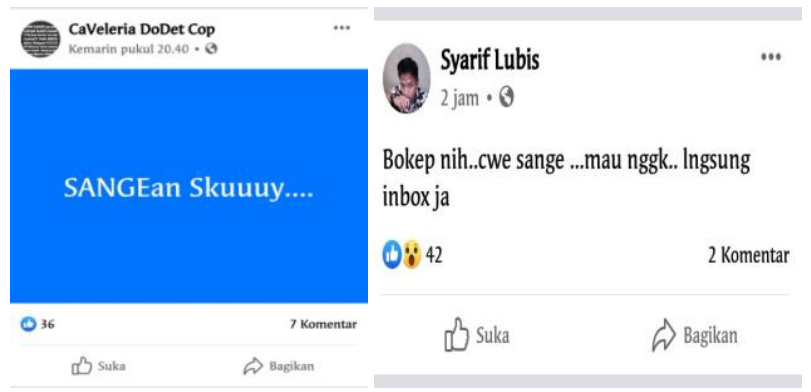

Figure 2. Words Frequently Used by Teens on Facebook Social Media Groups

\section{Adolescent criminal behavior is studied in youth groups}

The play environment also determines a teenager's learning process towards a better or a bad direction, because in this position it has a central role. Nearly half of human life is spent hanging out with friends, family, or girlfriends. As a social being that cannot be separated from other individuals, this depends on the place where the individual interacts. If they are in a good position socially, then their association will certainly be good, but if the position tends to be negative, their behavior will be affected by negative things. The following is an upload of Indonesian youth caption group members in Figure 3.

Figure 3. Whatsapp and Youtube links to the Indonesian Youth Caption Group

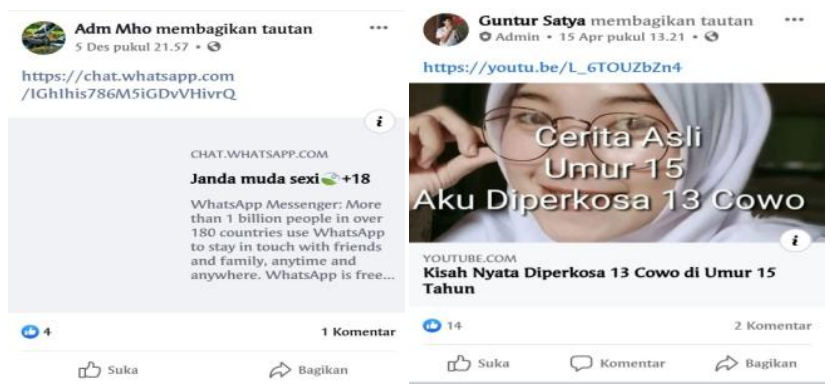

Figure 3. Whatsapp and Youtube links to the Indonesian Youth Caption Group

This condition is what happens to adolescents who are members of the Indonesian Youth Grub Caption. They hang out with so many negative friends that others will follow suit. Humans spend the act to socialize with the existing environment. Interestingly, there are many things in this interaction that can influence the behavior of an individual. Then the process of these activities will eventually lead to the same point. Sutherland stated that meetings focus on colleagues or family and groups as the most likely sources of initiation into delinquent values and activities (Bosiakoh \& Paul, 2010).

Based on the above, criminal behavior occurs from a close association between adolescents which results in many lessons on criminal acts and violates the norms they adopt from their group. The role of the family was directly replaced by the Indonesian Youth Grub Caption group which resulted in many definitions of criminal acts that were emulated from children's play environments.

\section{Mechanisms for studying criminal behavior}

Behavior that can harm others either morally or materially can be categorized as a criminal act and it violates the law. All criminal acts involve anti-social, moral, or despicable behavior. Criminal conduct is specifically prohibited in public. This is related to the social values adopted by society and the norms that apply in a society. Teenagers in Grub Caption Indonesian youth often upload pornographic videos to get the attention of other members. They do not realize that these posts violate all social customs such as norms of decency and religious norms. From uploading pornographic videos, it will allow teenagers to do the same thing in everyday life and then crime will emerge like videos uploaded by other members. 
Analysis of the Four Differential Dimensions of the Association on Youth Behavior in Indonesian Youth Grub Caption

Differential association theory (criminal tendency) varies in frequency, duration, priority, and intensity (Scarpitti, 2009). The difference in Sutherland's association cannot be called criminal if the four dimensions do not exist. The four dimensions are:

\section{a. Priority}

Priority is an association that is considered as a need for individuals to mingle in the group. This is because the Indonesian Youth Grub Caption is the second home for its members with many problems they face at home so they choose to play with their groups. Therefore they are looking for a place where this place becomes an escape for the problems they are experiencing in their daily life. At this point, the position of Indonesian Youth Grub Caption is an alternative solution for teenagers to vent their complaints about the problems they experience. Almost every day they upload videos, photos, links, or words to the Indonesian Youth Grub Caption. Which will give freedom to adolescents to do a lot of deviant behavior. Immoral acts are actions that violate the norms of decency. This is often found in the Indonesian Youth Grub Caption, namely by asking female members to make video calls without wearing clothes. Here are some captures on the Indonesian Youth Grub Caption in Figure 4.

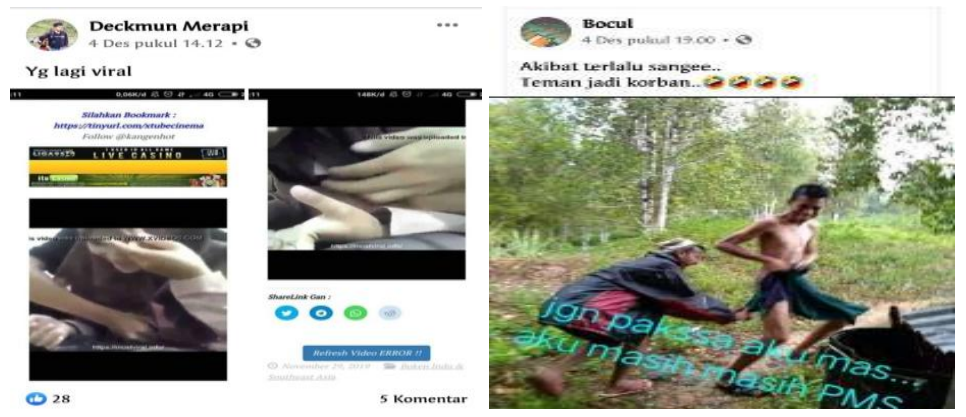

Figure 4. Captures on the Indonesian Youth Grub Caption

\section{b. Frequency}

Frequency is the number of definitions that are born in the social process. Here the researcher explains a process from the formation of the Indonesian Youth Grub Caption. The pioneer of the formation of this group started with teenagers who wanted to do social deviations together. As time goes on, the number of members has also increased. Within three years it already has 192,270 members, it shows that the interest and enthusiasm of youth are very high. However, this grub is made just for fun and fun without giving any positive impact. The amount of learning adopted in the association has resulted in definitions of criminal behavior or juvenile deviation. A definition of criminality is adopted by each member of the group because of the influence of daily behavior and it will allow a person to be caught in a criminal act or irregularity.

\section{c. Duration}

Duration is the amount of time that is often spent in the socializing process. From the duration of the Indonesian Youth Grub Caption, there is strong solidarity between its members. Almost every day they spend their time just writing words on grub. Many things happen when teenagers are in the grub, such as responding to comments and sometimes seeking attention by posting things. However, all these activities still lead to negative things because of the large number of pornographic uploads they distribute.

\section{d. Intensity}

Intensity is an association that occurs within a limited scope in the Indonesian Youth Grub Caption. This limitation is caused by the amount of competition to get more audiences, besides that because too often uploading things that deviate from teens will be influenced to do what they have uploaded into the grub.

\section{Social Control Analysis of Adolescent Deviant Behavior Discourse on Indonesian Youth Grub Caption}

Social control can be seen from the main function of socialization. How the relationship occurs, social control regarding discourse of adolescent deviant behavior can also be seen from the family which also means that the social unit responsible for it has become more important. This means that society and culture become dependent on the effectiveness of socialization, namely the extent to which the individual learns the values, attitudes, and behavior of the community and their families (Goode, 2020). 
Hirschi \& Gottfredson (2017) stated that crime occurs when a person's ties to society are weakened or broken. The main idea behind the control theory is that deviance is the result of a lack of control or social control. This theory is built on the view that every human being tends to disobey the law or have the urge to commit violations of the law. Like what members of the Indonesian Teenage Grub Caption, even though they already know what they are doing, they can deal with the law because they have spread content about pornography, but it is still done.

Therefore, control theorists assess deviant behavior as a logical consequence of a person's failure to obey the law. In this context, social control theory parallels conformity theory. Social control theory departs from the assumption or the assumption that individuals in society have the same likely tendency. The good and evil of a person completely dependent on society. The findings of researchers in the field show that the social ties of Indonesian Teenage Grub Caption members have weak social ties so that they tend to break the law because they feel a little bound by agreed-based regulations.

There are four main elements in Hirschi \& Gottfredson's (2017) mind map called Social Bonds which function to control individual behavior. The four main elements are described as follows:

1. Affection is a source of strength that arises from the results of socialization in the primary group (for example family) so that individuals have a strong commitment to obeying the rules. If the family institution has explained the values that must be obeyed, today's teenagers will never fall into negative things. Teens in the Indonesian Youth Grub Caption are an example of the weakness of family commitment in controlling the behavior of their children. If the commitment made is very strong, youth can control their behavior and leave the social deviance group they are following.

2. Strong responsibility for rules can provide a framework for awareness of the future. The form of this commitment, among others, is the awareness that his future will be bleak if he takes deviant actions. An environment where we can commit ourselves. Also, teenagers must be explained that if they are still joining the Indonesian Youth Grub Caption they will not have a good future, because to have a good future teenagers must avoid groups that have a bad impact.

3. Involvement will encourage individuals to behave in a participatory manner and be involved in the conditions set by society. The intensity of one's involvement in conventional normative activities will automatically reduce one's chances of committing illegal acts.

To keep teenagers away from matters relating to the law, it is best if community institutions provide opportunities for teenagers to participate in activities in the community. When teenagers are already busy with activities in society, there is no opportunity for teenagers to do things that are not useful, such as playing social media, following unclear groups, and taking deviant actions both in cyberspace and in everyday life.

4. Trust, loyalty and obedience to social norms or societal rules will eventually be firmly embedded in a person and that means social rules have been self-enforcing and their existence (for each individual) is also getting stronger. If adolescents who are members of the Indonesian Youth Grub Caption have a sense of obedience, trust, and obedience to the norms in society they will assume that they must hold fast to themselves, and then they will feel sorry for what they did. all this time it was a waste of time and their harm.

Horton \& Hunt (1996) revealed that the higher the level of awareness of one of the social institutions, such as churches, schools, and local organizations, the less likely it is for them to commit deviations. If adolescents have good kinship, community, education, and work roles, then they will be nurtured to comply with dominant norms. According to the researchers' observations, the more youthful activities in the Indonesian Youth Grub Caption, the more often they upload content or discourse that is not good for teens. If it is left like that it will become an activity that is usually done and over time it will make the mindset of adolescents not good. Therefore, social control is part of the solution to explore the activities in the group. Such activities can be eliminated if teenagers and also people who know can work together. This control can be in the form of control exercised by the family, community environment, as well as community and religious leaders who participate in social control because today's teenagers need advice from their surroundings. With these interrelationships, social control can be carried out together and an orderly condition will be created. This awareness requires control from influential parties in society, with social control finding and even fortifying these asocial activities.

Researchers use social control theory to analyze social control over juvenile delinquency because this theory can see social conditions, one of which is caused by apathy which can be explained by social control theory. The existence of juvenile delinquency that occurs in social media can be overcome by social control carried out by the surrounding environment and family, therefore control theory can explain how social control is exercised by residents and the causes of low social control to reduce juvenile delinquency. 


\section{Conclusion}

Based on the results and discussion that has been described, it can be concluded that:

1. Discourse on Deviant Behavior by Youth in the Facebook Social Media Grub, namely:

a. Sharing pornographic videos in the form of adult films or real videos of teenagers committing deviations, out of habit, and following what other grub members are doing.

b. Share pornographic links that can be accessed by members via YouTube or WhatsApp, are influenced by playgroups and vent things they cannot do in their daily lives.

c. Sharing pornographic photos for entertainment, being influenced by posts by fellow members, gaining audience and attention.

2. Words that are often used by teenagers on Facebook's social media group, namely:

a. Sange, a sentence for men who already understand the adult world, is often used in everyday life, especially teenage boys, slang, and words that lead to negative and dirty things.

b. For WhatsApp, the aim is to get broad insights and friendships, exchange contacts with other teenagers who are members of grub, join grub on the new WhatsApp, and get viral videos.

c. Chat for women because they are accustomed to seeing complaints made by young women, are interesting, and feel bored with male friendships.

\section{References}

Barnes, S. B. (2006). A privacy paradox: Social networking in the United States. First Monday. 11(9)

Bosiakoh, T. A., \& Paul, K. (2010). Differential association theory and juvenile delinquency in Ghanas capital city-Accra: The case of Ghana borstal institute. International Journal of sociology and Anthropology, 2(9), 198-205.

Budiman, A. (2004). Pengantar Analisis Wacana. Universitas Muhammadiyah Malang.

Burgess, R. L., \& Akers, R. L. (1966). A differential association-reinforcement theory of criminal behavior. Social problems, 14(2), 128-147.

Chaer, A. (2007). Kajian bahasa: struktur internal, pemakaian, dan pemelajaran. Rineka Cipta.

Cohen, B. J. (2003). Theory and practice of psychiatry. Oxford University Press.

Cormode, G., \& Krishnamurthy, B. (2008). Key differences between Web 1.0 and Web 2.0. First Monday, 13(6)

Darma, Y. A. (2014). Analisis Wacana Kritis dalam Multiperspektif. Bandung: PT. Refika Aditama.

DeBell, M., \& Chapman, C. (2006). Computer and Internet Use by Students in 2003. Statistical Analysis Report. NCES 2006-065. National Center for Education Statistics.

Dowdell, E. B., Burgess, A. W., \& Flores, J. R. (2011). Online social networking patterns among adolescents, young adults, and sexual offenders. AJN The American Journal of Nursing, 111(7), 28-36.

Goodson, I., \& Deakin Crick, R. (2009). Curriculum as narration: tales from the children of the colonised. The Curriculum Journal, 20(3), 225-236.

Downs, D. (2005). Pornography. Dalam Microsoft Encarta Reference Library.

Engel, V. J. L. (2012). Upaya Melindungi Anak-anak Dari Fornografi Di Internet. Jurnal Sosioteknologi, 11(25), 60-65.

GOODE, W. J. (2020). Family systems and social mobility. Families in East and West: Socialization process and kinship ties, 120.

Greenhow, C., \& Robelia, B. (2009). Old communication, new literacies: Social network sites as social learning resources. Journal of Computer-Mediated Communication, 14(4), 1130-1161.

Gunarsa, S. D. (2004). Bunga rampai psikologi perkembangan dari anak sampai usia lanjut. Jakarta: BPK.

Hidayati, K. B., \& Farid, M. (2016). Konsep Diri, Adversity Quotient dan Penyesuaian Diri pada Remaja. Persona: Jurnal Psikologi Indonesia, 5(02).

Hirschi, T., \& Gottfredson, M. R. (2017). The distinction between crime and criminality. In The Craft of Criminology (pp. 187-202). Routledge.

Horton, P. B., \& Hunt, C. L. (1996). Sosiologi (terjemahan Aminudi Ram dan Tita Sobari). Jakarta: Erlangga.

Jacky, M. (2015). Sosiologi konsep, teori, dan metode. Jakarta: Mitra Wacana Media.

Johnstone, B. (2017). Discourse analysis. John Wiley \& Sons.

Jurgenson, N. (2012). When atoms meet bits: Social media, the mobile web and augmented revolution. Future internet, 4(1), 83-91.

Kartono, K. (2014). Patologi sosial jilid 2: Kenakalan remaja. Jakarta: Rajawali Pers.

Kemp, S. (2018). Digital in 2018: World's internet users pass the 4 billion mark. We are social, 30. 
Lenhart, A., Arafeh, S., Smith, A., \& Macgill, A. R. (2008). Writing, Technology and Teens. Washington, DC: Pew Internet \& American Life Project.

Li, X. (2009). A Daoist perspective on internationalizing curriculum. Curriculum inquiry, 39(1), 179-192.

Moleong, L. J. (2017). Metodologi Penelitian Kualitatif (36th ed.; I. Taufik, Ed.). PT Remaja Rosdakarya, April 2017

Mulyana, D. (2005). Kajian Wacana: Teori, Metode, dan Aplikasi Prinsip-prinsip Analisis Wacana. Yogyakarta: Tiara Wacana.

Mulyasa, E. (2012). Manajemen dan kepemimpinan kepala sekolah. Jakarta: Bumi Aksara.

Narwoko, J. D., \& Suyanto, B. (2010). Sosiologi Teks Pengantar dan Terapan Edisi Ketiga. Jakarta: Prenada Media Group.

Nomor, U. U. R. I. (20). Tahun 2003 tentang sistem pendidikan nasional.

Pescosolido, B. A. (2011). The Sociology of Social Networks, 21st Century Sociology.

O'Keeffe, G. S., \& Clarke-Pearson, K. (2011). The impact of social media on children, adolescents, and families. Pediatrics, 127(4), 800-804.

Rochaniningsih, N. S. (2014). Dampak pergeseran peran dan fungsi keluarga pada perilaku menyimpang remaja. Jurnal Pembangunan Pendidikan: Fondasi dan Aplikasi, 2(1).

Scarpitti, FR., AL Nielsen., \& JM Miller. (2009). "A Sociological Theory of Criminal Behavior." Pp. 211 in Crime and Criminals Contemporary and Classic Readings in Criminology (2nd ed.). New York

Social, W. A. (2018). Global digital report 2018. New York: We Are Social.

Staksrud, E., Ólafsson, K., \& Livingstone, S. (2013). Does the use of social networking sites increase children's risk of harm?. Computers in human behavior, 29(1), 40-50.

Sumarlam, M. S. (2003). Teori dan Praktik Analisis Wacana. Pustaka Cakra, Surakarta.

Ybarra, M. L., Diener-West, M., \& Leaf, P. J. (2007). Examining the overlap in Internet harassment and school bullying: Implications for school intervention. Journal of Adolescent health, 41(6), S42-S50. 